\title{
Manometry of the Human lleum and lleocaecal Junction in Health, Disease and Surgery: A Systematic Review
}

\section{OPEN ACCESS}

Edited by:

Dirk Weyhe,

Klinik für Allgemein- und

Viszeralchirurgie, Universitätsklinik für Viszeralchirurgie, Pius-Hospital

Oldenburg, Germany

Reviewed by:

Beate Richter,

Friedrich Schiller University

Jena, Germany

Cihangir Akyol,

Ankara University, Turkey

${ }^{*}$ Correspondence:

Chen Liu

chenliu818@gmail.com

Specialty section: This article was submitted to

Visceral Surgery,

a section of the journal

Frontiers in Surgery

Received: 18 September 2019 Accepted: 20 March 2020

Published: 15 April 2020

Citation:

Liu C, Saw KS, Dinning PG,

O'Grady G and Bissett I (2020)

Manometry of the Human lleum and lleocaecal Junction in Health, Disease and Surgery: A Systematic Review.

Front. Surg. 7:18.

doi: 10.3389/fsurg.2020.00018

\author{
Chen Liu ${ }^{1 *}$, Kai Sheng Saw ${ }^{1}$, Phil G. Dinning ${ }^{2}$, Gregory O'Grady ${ }^{1}$ and lan Bissett ${ }^{1}$ \\ ${ }^{1}$ Department of Surgery, University of Auckland, Auckland, New Zealand, ${ }^{2}$ Departments of Gastroenterology and Surgery, \\ Flinders Medical Centre, Flinders University, Adelaide, SA, Australia
}

Background: The terminal ileum and ileocaecal junction form a transition zone in a relatively inaccessible portion of the gastrointestinal tract. Little is known about the motility of this region with few detailed studies, indicating the need for a robust synthesis of current knowledge. This review aimed to evaluate the quantitative and qualitative data on the manometry findings of the terminal ileum and ileocaecal junction during the fasting and post-prandial periods in healthy individuals and patients with motility disorders or patients after bowel surgery.

Methods: A systematic search of five databases (Medline, Pubmed, Embase, Scopus, and Cochrane Library) was performed. Studies that presented manometry data from the human ileum or ileocaecal junction were included.

Results: Forty-two studies met the inclusion criteria. The main motility patterns reported in the terminal ileum during fasting were the migrating motor complex, discrete clustered contractions, prolonged propagated contractions and phasic contractions. Post-prandial motility featured irregular, intense contractions. Some studies found a region of sustained increased pressure at the ileocaecal junction while others did not. Patients with motility disorders showed differences in manometry including retrograde propagation of phase III. Patients post-bowel surgery showed differences including higher incidence of phase III.

Conclusion: Motility patterns of the terminal ileum differ between fasting and fed states. Large variability existed in manometry recordings of the terminal ileum. Technical challenges and lack of standardized definitions may reduce accuracy of manometry assessment. Further research is needed to understand how this key portion of the gut physiologically functions.

Keywords: manometry, ileum, terminal ileum, ileocaecal junction, motility, small bowel

\section{INTRODUCTION}

\section{Rationale}

The terminal ileum is an important junctional zone with specialized functions. This region of the small bowel is involved in the active absorption of bile acids and vitamin B12 $(1,2)$, and the ileocaecal junction (ICJ) helps to coordinate efflux of contents to the colon while preventing coloileal reflux $(3,4)$. These functions help to maintain gut homeostasis by helping to regulate the 
transit of fluid into the colon to a volume that is within its absorptive capacity ( $\sim 1.5 \mathrm{~L}$ of chyme per day) (5), while also separating the dense microbiota of the large bowel from the ileum (6).

Despite its importance, accurate assessment of the motility profile of the ileum in humans has been limited. Unlike the ileum, there is an abundance of manometry studies involving both the upper gastrointestinal tract (including jejunum) and the large bowel. The terminal ileum has received less attention, likely due to its relative inaccessibility (7).

Obtaining accurate motility information from the terminal ileum has important clinical implications, by informing normal physiology and pathophysiology. For example, disturbances of the Migrating Motor Complex (MMC) pattern have been proposed in the proximal small bowel of patients with a variety of gastrointestinal disorders, ranging from bacterial overgrowth and systemic sclerosis to myotonic dystrophy and chronic idiopathic intestinal pseudo-obstruction (8-11). To date, only a small number of studies have focused on ileal manometry abnormalities in motility disorders such as irritable bowel syndrome (IBS) and chronic idiopathic constipation $(12,13)$.

There have been no attempts in the literature to consolidate and evaluate the available data pertaining to manometry of the terminal ileum in the context of health, motility disorders or bowel surgery. Performing such a review would consolidate and synthesize the knowledge researchers have gained thus far, and also highlight limitations and direct future areas of investigation.

\section{Objectives and Research Questions}

This systematic review therefore had three key objectives:

1. Evaluate the quantitative and qualitative data on the manometry findings of the terminal ileum and ileocaecal junction in normal healthy human subjects during the interdigestive and post-prandial periods.

2. Evaluate known manometry findings of the terminal ileum in patients with motility disorders.

3. Evaluate known manometry findings of the terminal ileum in patients who have undergone bowel surgery, such as loop ileostomy.

\section{METHODS}

\section{Study Design}

The systematic review was conducted in accordance with the checklist of reporting items within the PRISMA guidelines (14).

\section{Systematic Review Protocol}

A systematic literature search of the Ovid Medline, Pubmed, Embase, Scopus, and Cochrane Library databases was performed. All studies that featured original research in which manometry data were collected from the terminal ileum were included. Exclusion criteria were studies that did not specifically describe data from the ileum, review articles, letters to the editor, case reports and conference abstracts. Studies that focused on ileal pouches following proctocolectomy were only included if manometry data was also collected proximal to the pouch.
Searches were performed concurrently and independently by two authors (CL and KS). Titles and abstracts were screened based on the above criteria. Full texts were then reviewed to confirm eligibility. In cases where there was insufficient information from title and abstract alone, full texts were obtained and screened. Group consensus was required for study inclusion and any disputes were adjudicated by a senior author (IB).

\section{Search Strategy}

An example of the search strategy used is as follows: ["ileum" (keywords and mesh) OR "ileocaecal valve (keywords and mesh)] AND ["manometry" (keywords and mesh) or "manometer*" (keyword)]. Studies were restricted to human subjects and English language. No limits were applied to the time of publication or age of participants. The reference bibliographies of all included articles were hand searched to identify any other relevant studies.

\section{Data Extraction}

Data were extracted by a single author (CL) into a summary table and the accuracy was then checked by a second author (KS). Attempts were made to contact the study author via e-mail if the reported data contained a suspected error or a major discrepancy.

Details of the study design were collected including type of participant (i.e., healthy volunteers vs. motility disorder patients vs. bowel surgery patients) and the duration of manometry recording (fasting and post-prandial). Specifications of the manometry recording technique were also collected, such as the type of manometry catheter, the number of sensors and inter-sensor spacing.

Quantitative information regarding the pressure profiles of motility events were collected, including the incidence of the event, contraction frequency, amplitude, duration, and propagation velocity and distance. Qualitative information was also collected, including authors' definitions of various motility phenomena, descriptions of motility events, and comments on the strengths and weaknesses of their manometry technique.

\section{Data Analysis}

Quantitative data related to healthy patients were analyzed separately to data from patients with motility disorders, which in turn were analyzed separately from patients after bowel surgery. It became apparent after this categorization that there were often very few data points per analyzed parameter. In addition, there was significant heterogeneity of motility pattern definitions adopted by different studies. For these reasons, no quantitative meta-analysis was performed. Summary descriptive statistics were instead formulated and presented for each parameter, with a narrative synthesis of overall findings.

No specific bias evaluation tools or scores were employed given the significant heterogeneity of study designs, manometry recording techniques and participant populations. The potential limitations pertaining to the methodology of each study were evaluated and highlighted in a summary table. 


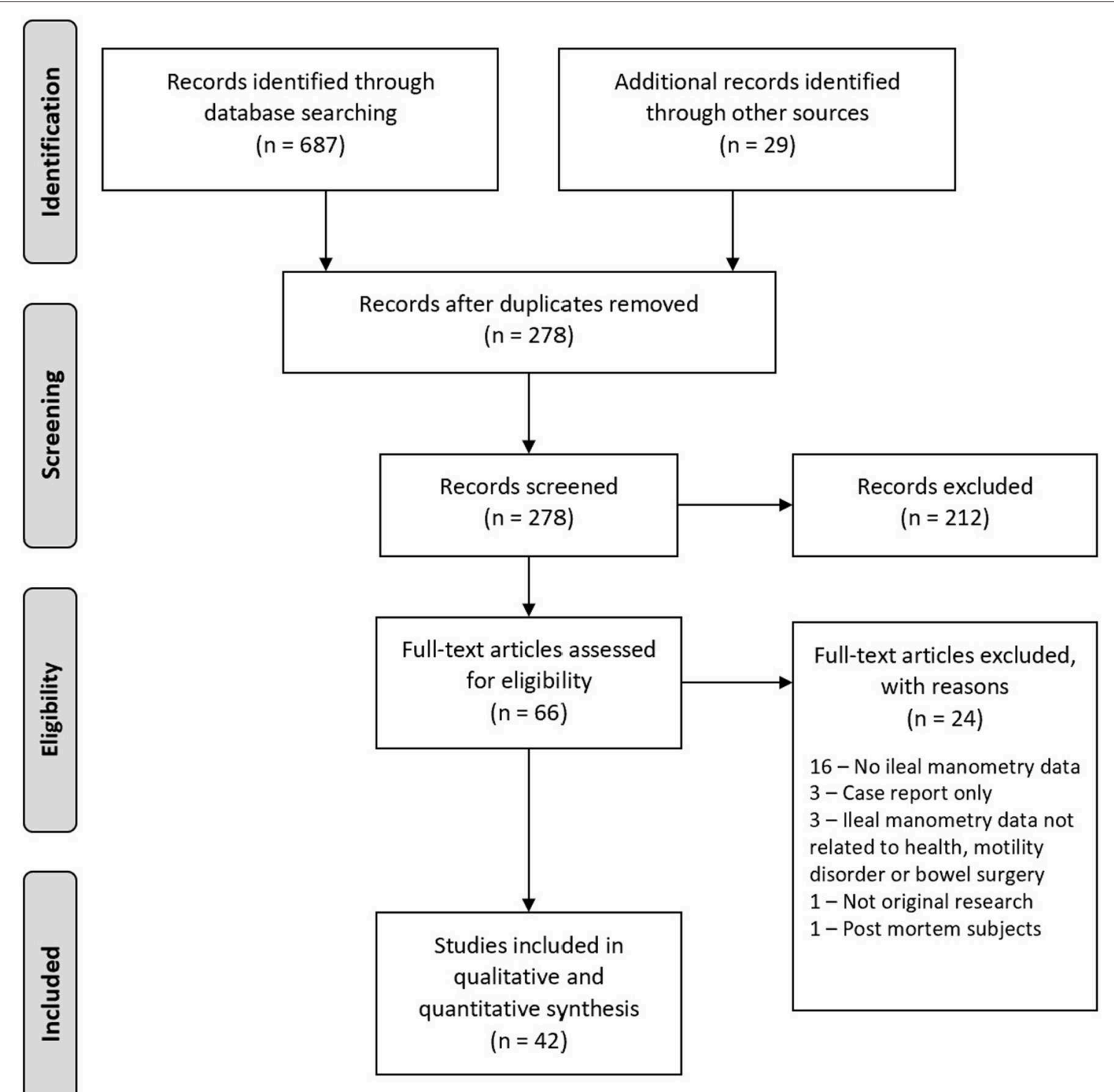

FIGURE 1 | PRISMA flow diagram.

\section{RESULTS}

\section{Flow Diagram}

The PRISMA flow diagram (14) is presented in Figure 1, including the reasons for exclusion following full text review.

\section{Study Selection and Characteristics}

The initial search found a total of 687 articles. After exclusion of duplicates and initial screening of titles and abstracts, 66 articles underwent full text review, from which 42 original research articles were included.

The characteristics of the included studies are presented in Table 1. Twenty-eight studies contained data on healthy volunteers, five studies featured motility disorder patients, and
16 studies featured bowel surgery patients, including 10 studies that used an ileostomy as a manometry access point. One study involved a pediatric population (47).

\section{Synthesized Findings}

Definitions of Motility Patterns

The most common ileal motility patterns reported were the migrating motor complex (MMC) and its three phases (I, II, and III), discrete clustered contractions (DCC), prolonged propagated contractions (PPC) and phasic contractions. Significant variability existed in the definitions of these terms. There was variability in the definitions' levels of detail. For example, five studies defined "Phase I" of the MMC as simply a period of motor quiescence $(29,36,46,47,51)$. However, 
TABLE 1 | Details of included articles.

\begin{tabular}{|c|c|c|c|c|c|c|c|c|}
\hline \multirow[t]{2}{*}{ References } & \multirow[t]{2}{*}{ Study population } & \multirow{2}{*}{$\begin{array}{l}\text { Study size (no. of } \\
\text { patients) }\end{array}$} & \multicolumn{2}{|c|}{ Duration of recording (h) } & \multirow{2}{*}{$\begin{array}{l}\text { Type of } \\
\text { manometry } \\
\text { assembly }\end{array}$} & \multirow{2}{*}{$\begin{array}{c}\text { No. of sensors in } \\
\text { TI }\end{array}$} & \multirow{2}{*}{$\begin{array}{c}\text { Spacing } \\
\text { between } \\
\text { sensors }(\mathrm{cm})\end{array}$} & \multirow[t]{2}{*}{ Limitations } \\
\hline & & & Fasting & Post-prandial & & & & \\
\hline Accarino et al. (15) & $\begin{array}{l}\text { Salmonella patients and } \\
\text { healthy volunteers }\end{array}$ & $\begin{array}{l}22 \text { (12 healthy, } 10 \\
\text { with Salmonella) }\end{array}$ & 6 & 0 & Perfused catheter & 4 & 20 & $\begin{array}{l}\text { No post-prandial recording, } \\
\text { large sensor spacing }\end{array}$ \\
\hline Barberani et al. (16) & $\begin{array}{l}\text { Ileostomy patients and } \\
\text { healthy volunteers } \\
\text { undergoing colonoscopy }\end{array}$ & $\begin{array}{l}29 \text { (nine with } \\
\text { ileostomy, } 20 \\
\text { healthy) }\end{array}$ & $5-20 \mathrm{~min}$ & 0 & Perfused catheter & $3-4$ & $0.4-5$ & $\begin{array}{l}\text { Short recording duration, no } \\
\text { post-prandial recording, } \\
\text { need for bowel prep }\end{array}$ \\
\hline Bassotti et al. (17) & $\begin{array}{l}\text { Proctocolectomy patients } \\
\text { with J-shaped lleal } \\
\text { Reservoir }\end{array}$ & 6 & 1.5 & 1 & Perfused catheter & $\begin{array}{l}\text { two in ileum, two } \\
\text { in pouch }\end{array}$ & 5 & $\begin{array}{l}\text { Short recording duration, } \\
\text { limited number of sensors }\end{array}$ \\
\hline Borody et al. (18) & Healthy volunteers & 16 & $6-8$ & 5 & Perfused catheter & 9 & $1.5-20$ & $\begin{array}{l}\text { Large sensor spacing for } \\
\text { some sensors }\end{array}$ \\
\hline Castell et al. (19) & Colonic bypass patients & 3 & Unknown & Unknown & Perfused catheter & 3 & 5 & $\begin{array}{l}\text { Unknown duration of } \\
\text { recording }\end{array}$ \\
\hline Code et al. (20) & lleostomy patients & 2 & $19-28.5$ & 1 & $\begin{array}{l}\text { Photokymograph } \\
\text { with tandem } \\
\text { balloons }\end{array}$ & 2 & 3 & $\begin{array}{l}\text { Small study size, limited } \\
\text { number of sensors }\end{array}$ \\
\hline Coffin et al. (21) & Healthy volunteers & 10 & 1 & 2 & Perfused catheter & 3 & $5-10$ & $\begin{array}{l}\text { Short recording duration, } \\
\text { large sensor spacing }\end{array}$ \\
\hline Cohen et al. (3) & $\begin{array}{l}\text { Colonic exclusion and } \\
\text { colostomy patients }\end{array}$ & 5 & $<1$ & 0 & Perfused catheter & 1 & N/A & $\begin{array}{l}\text { Short recording duration, } \\
\text { only one sensor in } \mathrm{Tl}, \mathrm{no} \\
\text { post-prandial recording }\end{array}$ \\
\hline Corazziari et al. (22) & $\begin{array}{l}\text { Healthy volunteers } \\
\text { undergoing colonoscopy }\end{array}$ & 11 & $<1$ & 0 & Perfused catheter & 3 & 0.4 & $\begin{array}{l}\text { Short recording duration, } \\
\text { need for bowel prep }\end{array}$ \\
\hline Cummins (23) & lleostomy patients & 5 & Unknown & Unknown & $\begin{array}{l}\text { Kymograph with } \\
\text { rubber balloon }\end{array}$ & 1 & N/A & $\begin{array}{l}\text { Unknown recording } \\
\text { duration, only one sensor }\end{array}$ \\
\hline Daniel et al. (24) & lleostomy patients & 4 & 0.5 & $1.5-3.5$ & $\begin{array}{l}\text { Perfused catheter } \\
\text { with balloon }\end{array}$ & 1 & N/A & $\begin{array}{l}\text { Short fasting recording } \\
\text { duration, only one sensor }\end{array}$ \\
\hline Dinning et al. (25) & Healthy volunteers & 14 & \multicolumn{2}{|c|}{24 (with three meals during this period) } & $\begin{array}{l}\text { Perfused catheter } \\
\text { (silastic) }\end{array}$ & 5 & 7.5 & Large sensor spacing \\
\hline Dinning et al. (4) & Ileostomy patients & 10 & 2 & 2 & $\begin{array}{l}\text { Perfused catheter } \\
\text { (silicon) }\end{array}$ & 6 & $5-7.5$ & $\begin{array}{l}\text { Short recording period, } \\
\text { large sensor spacing }\end{array}$ \\
\hline Dinning et al. (26) & Healthy volunteers & 6 & 1 & 3 & $\begin{array}{l}\text { Perfused catheter } \\
\text { (silastic) }\end{array}$ & Unknown & 7.5 & $\begin{array}{l}\text { Short recording period, } \\
\text { large sensor spacing, } \\
\text { number of sensors in TI } \\
\text { unknown }\end{array}$ \\
\hline Dinning et al. (27) & Healthy volunteers & 6 & 0 & $4-6$ & $\begin{array}{l}\text { Perfused catheter } \\
\text { (silicon) }\end{array}$ & $\geq 4$ & 7.5 & $\begin{array}{l}\text { No fasting recording, large } \\
\text { sensor spacing }\end{array}$ \\
\hline Gorard et al. (28) & $\begin{array}{l}\text { IBS patients and healthy } \\
\text { volunteers }\end{array}$ & $\begin{array}{l}20 \text { (eight with IBS, } \\
12 \text { healthy) }\end{array}$ & $\sim 17$ per patient & 0 & $\begin{array}{l}\text { Solid state } \\
\text { catheter }\end{array}$ & 1 & N/A & $\begin{array}{l}\text { No post-prandial recording, } \\
\text { only one sensor in } \mathrm{TI}\end{array}$ \\
\hline Groom et al. (29) & $\begin{array}{l}\text { Proctocolectomy patients } \\
\text { with ileoanal pouch }\end{array}$ & 12 & \multicolumn{2}{|c|}{24 (patient able to eat as usual) } & $\begin{array}{l}\text { Solid state } \\
\text { catheter }\end{array}$ & 5 & 20 & Large sensor spacing \\
\hline
\end{tabular}


TABLE 1 | Continued

\begin{tabular}{|c|c|c|c|c|c|c|c|c|}
\hline \multirow[t]{2}{*}{ References } & \multirow[t]{2}{*}{ Study population } & \multirow{2}{*}{$\begin{array}{l}\text { Study size (no. of } \\
\text { patients) }\end{array}$} & \multicolumn{2}{|c|}{ Duration of recording (h) } & \multirow{2}{*}{$\begin{array}{l}\text { Type of } \\
\text { manometry } \\
\text { assembly }\end{array}$} & \multirow{2}{*}{$\begin{array}{c}\text { No. of sensors in } \\
\mathrm{TI}\end{array}$} & \multirow{2}{*}{$\begin{array}{c}\text { Spacing } \\
\text { between } \\
\text { sensors }(\mathrm{cm})\end{array}$} & \multirow[t]{2}{*}{ Limitations } \\
\hline & & & Fasting & Post-prandial & & & & \\
\hline Hammer et al. (30) & Healthy volunteers & 13 & 1 & $\sim 4$ & Perfused catheter & $3-4$ & $10-20$ & $\begin{array}{l}\text { Short fasting recording } \\
\text { duration, large sensor } \\
\text { spacing }\end{array}$ \\
\hline Kachel et al. (31) & Healthy volunteers & 9 & $\sim 6.5$ & 0 & Perfused catheter & 2 & 50 & $\begin{array}{l}\text { No post-prandial recording, } \\
\text { limited number of sensors, } \\
\text { large sensor spacing }\end{array}$ \\
\hline Kamath et al. (32) & Healthy volunteers & 23 & 7 & 0 & Perfused catheter & 3 & Unknown & $\begin{array}{l}\text { No post-prandial recording, } \\
\text { unknown sensor spacing }\end{array}$ \\
\hline Kellow et al. (33) & Healthy volunteers & 16 & $15-29$ & $1.5-4$ & Perfused catheter & 4 & $10-15$ & Large sensor spacing \\
\hline Kellow et al. (34) & Healthy volunteers & 8 & N/A & 3 & Perfused catheter & $3-6$ & $10-20$ & $\begin{array}{l}\text { No fasting recording, large } \\
\text { sensor spacing }\end{array}$ \\
\hline Kellow et al. (35) & $\begin{array}{l}\text { IBS patients and healthy } \\
\text { volunteers }\end{array}$ & $\begin{array}{c}32 \text { (16 with IBS, } 16 \\
\text { healthy) }\end{array}$ & $12-29$ & Mean $1.8-2.2$ & Perfused catheter & 4 & Unknown & Unknown sensor spacing \\
\hline Kellow et al. (12) & $\begin{array}{l}\text { IBS patients and healthy } \\
\text { volunteers }\end{array}$ & $\begin{array}{l}24 \text { (16 with IBS, } \\
\text { eight healthy) }\end{array}$ & Overnight & 3 & Perfused catheter & $3-6$ & Unknown & Unknown sensor spacing \\
\hline Kerlin et al. (7) & Healthy volunteers & 11 & 6 & 6 & Perfused catheter & Unknown & 20 & Unknown sensor number \\
\hline Kerlin et al. (36) & Healthy volunteers & 10 & 6 & 6 & Perfused catheter & Unknown & 20 & Unknown sensor number \\
\hline Kerlin et al. (37) & Healthy volunteers & 6 & \multicolumn{2}{|c|}{24 (with three meals during this period) } & Perfused catheter & $1-2$ & 40 & $\begin{array}{l}\text { Limited number of sensors, } \\
\text { large sensor spacing }\end{array}$ \\
\hline Luiking et al. (38) & Healthy volunteers & 8 & $\sim 8.5$ & 0 & $\begin{array}{l}\text { Perfused catheter } \\
\text { (silicon) }\end{array}$ & 5 & 12.5 & $\begin{array}{l}\text { No post-prandial recording, } \\
\text { large sensor spacing }\end{array}$ \\
\hline Miedema et al. (39) & $\begin{array}{l}\text { Proctocolectomy with ileal } \\
\text { pouch-anal anastomosis } \\
\text { and loop ileostomy }\end{array}$ & 8 & 3 & 3 & Perfused catheter & 3 & 5 & $\begin{array}{l}\text { Short recording period, } \\
\text { limited number of sensors }\end{array}$ \\
\hline Miedema et al. (40) & $\begin{array}{l}\text { Proctcolectomy with ileal } \\
\text { pouch-anal anastomosis } \\
\text { and loop ileostomy }\end{array}$ & 13 & 3 & 3 & Perfused catheter & 3 & 5 & $\begin{array}{l}\text { Short recording period, } \\
\text { limited number of sensors }\end{array}$ \\
\hline Nasmyth et al. (41) & Ileostomy patients & 7 & Unknown & Unknown & Perfused catheter & 2 & $6-8$ & $\begin{array}{l}\text { Unknown duration of } \\
\text { recording, limited number of } \\
\text { sensors, large sensor } \\
\text { spacing }\end{array}$ \\
\hline Panagamuwa et al. (13) & $\begin{array}{l}\text { Chronic idiopathic } \\
\text { constipation patients and } \\
\text { healthy volunteers }\end{array}$ & $\begin{array}{l}16 \text { (10 with } \\
\text { constipation, six } \\
\text { healthy) }\end{array}$ & \multicolumn{2}{|c|}{24 (patient able to eat as usual) } & $\begin{array}{l}\text { Silicone-coated } \\
\text { catheter }\end{array}$ & 2 & 15 & $\begin{array}{l}\text { Limited number of sensors, } \\
\text { large sensor spacing }\end{array}$ \\
\hline Penagini et al. (42) & Healthy volunteers & 10 & 0 & 5.5 & Perfused catheter & $3-5$ & 7.5 & $\begin{array}{l}\text { No fasting recording, large } \\
\text { sensor spacing }\end{array}$ \\
\hline Pescatori (43) & $\begin{array}{l}\text { Proctocolectomy with } \\
\text { ileoanal reservoir }\end{array}$ & 7 & 3 & 1 & Perfused catheter & 3 & Unknown & $\begin{array}{l}\text { Short recording duration, } \\
\text { limited number of sensors, } \\
\text { unknown sensor spacing }\end{array}$ \\
\hline
\end{tabular}


TABLE 1 | Continued

\begin{tabular}{|c|c|c|c|c|c|c|c|c|}
\hline \multirow[t]{2}{*}{ References } & \multirow[t]{2}{*}{ Study population } & \multirow{2}{*}{$\begin{array}{l}\text { Study size (no. of } \\
\text { patients) }\end{array}$} & \multicolumn{2}{|c|}{ Duration of recording (h) } & \multirow{2}{*}{$\begin{array}{l}\text { Type of } \\
\text { manometry } \\
\text { assembly }\end{array}$} & \multirow{2}{*}{$\begin{array}{c}\text { No. of sensors in } \\
\mathrm{TI}\end{array}$} & \multirow{2}{*}{$\begin{array}{c}\text { Spacing } \\
\text { between } \\
\text { sensors }(\mathrm{cm})\end{array}$} & \multirow[t]{2}{*}{ Limitations } \\
\hline & & & Fasting & Post-prandial & & & & \\
\hline Posey and Bargen (44) & lleostomy patients & 10 & 0 & $1-3$ & $\begin{array}{l}\text { Photokymograph } \\
\text { with tandem } \\
\text { balloons }\end{array}$ & 2 & Unknown & $\begin{array}{l}\text { No fasting recording, short } \\
\text { post-prandial recording } \\
\text { duration, limited number of } \\
\text { sensors, unknown sensor } \\
\text { spacing }\end{array}$ \\
\hline Quigley et al. (45) & Healthy volunteers & 22 & $6-22$ & 12 & Perfused catheter & $\sim 8$ & $1.5-25$ & Some large sensor spacing \\
\hline Seidl et al. (46) & Healthy volunteers & 10 & \multicolumn{2}{|c|}{24 (with one standardized meal) } & $\begin{array}{l}\text { Polyurethane } \\
\text { catheter with } \\
\text { piezoresistive } \\
\text { pressure sensors }\end{array}$ & Unknown & 3 & $\begin{array}{l}\text { Unknown number of } \\
\text { sensors in } \mathrm{TI}\end{array}$ \\
\hline Sood et al. (47) & $\begin{array}{l}\text { lleostomy patients and } \\
\text { endorectal pull-through } \\
\text { patients }\end{array}$ & $\begin{array}{l}29 \text { (23 with } \\
\text { ileostomy, six with } \\
\text { endorectal } \\
\text { pull-through) }\end{array}$ & $1-4$ & $1-4$ & Perfused catheter & $4-8$ & $5-15$ & $\begin{array}{l}\text { Variable duration of } \\
\text { recording, large sensor } \\
\text { spacing }\end{array}$ \\
\hline Spiller et al. (48) & Healthy volunteers & 13 & Overnight & 5 & Perfused catheter & 6 & $4-10$ & Some large sensor spacing \\
\hline Spiller et al. (49) & Healthy volunteers & 15 & Overnight & 2 & Perfused catheter & $7-8$ & $4-10$ & Some large sensor spacing \\
\hline Stryker et al. (50) & $\begin{array}{l}\text { Proctocolectomy patients } \\
\text { with ileal pouch-anal } \\
\text { anastomosis and healthy } \\
\text { volunteers }\end{array}$ & $\begin{array}{l}14 \text { (eight with } \\
\text { proctocolectomy } \\
\text { and } 6 \text { healthy) }\end{array}$ & $16-23$ & 6 & Perfused catheter & Unknown & $10-25$ & $\begin{array}{l}\text { Unknown number of } \\
\text { sensors in } \mathrm{Tl} \text {, large sensor } \\
\text { spacing }\end{array}$ \\
\hline Van Ooteghem et al. (51) & Healthy volunteers & 8 & Unknown & 0 & $\begin{array}{l}\text { Perfused catheter } \\
\text { (silicon) }\end{array}$ & 8 & 10 & $\begin{array}{l}\text { Unknown duration of fasting } \\
\text { recording, no post-prandial } \\
\text { recording, large sensor } \\
\text { spacing }\end{array}$ \\
\hline
\end{tabular}


TABLE 2 | Summary definitions of the most common ileal manometry motility terms.

\begin{tabular}{|c|c|c|c|}
\hline Ileal motility pattern & Pattern similar to... & $\begin{array}{l}\text { No. of studies with } \\
\text { definition (References) }\end{array}$ & Summary definition \\
\hline \multirow[t]{2}{*}{ MMC } & & $\begin{array}{c}8 \\
(7,12,15,28,29,31,46,51)\end{array}$ & Motor quiescence \\
\hline & & $\begin{array}{c}6 \\
(7,13,15,29,31,46,47,51)\end{array}$ & Irregular contractile activity \\
\hline Phase III & & $\begin{array}{c}18 \\
(7,13,15,17,18,28,29 \\
31,33-38,45-47,50,51)\end{array}$ & $\begin{array}{l}\text { Regular sustained contractions, with a } \\
\text { minimum duration of } 3 \text { min, and minimum } \\
\text { contraction frequency of } 8 \text { per minute }\end{array}$ \\
\hline Discrete clustered contractions & $\begin{array}{l}\text { Migrating clustered contractions (46), } \\
\text { Propagating sequence }(4,26,27) \text {, Type III } \\
\text { and Type IV waves }(20,23,24,44)\end{array}$ & $\begin{array}{c}12(12,18,25,26,28,29 \\
35,39,40,45,47,50)\end{array}$ & $\begin{array}{l}\text { A group of phasic contractions, with } \\
\text { maximum duration of } 3 \mathrm{~min} \text {, and } \\
\text { contraction frequency up to } 12 \text { per minute }\end{array}$ \\
\hline Prolonged propagated contraction & $\begin{array}{l}\text { Propagated contractions (35), Large } \\
\text { pressure waves (48) }\end{array}$ & $\begin{array}{l}14(12,15,17,18,25,29 \\
32,39,40,42,45-47,50)\end{array}$ & $\begin{array}{l}\text { A single wave, with minimum duration of } \\
6 s \text { and minimum amplitude of } 20 \mathrm{mmHg} \\
\text { that propagates }\end{array}$ \\
\hline Regular phasic contraction & Type I waves $(20,23,24,44)$ & $2(16,22)$ & $\begin{array}{l}\text { Wave peak with rate of pressure increase } \\
>4 \mathrm{mmHg} / \mathrm{sec} \text {, and lasting } \leq 8 \mathrm{~s}\end{array}$ \\
\hline Prolonged phasic contraction & Type II waves $(20,23,24,44)$ & $2(16,22)$ & $\begin{array}{l}\text { Wake peak with rate of pressure increase } \\
>4 \mathrm{mmHg} / \mathrm{sec} \text {, and lasting }>8 \mathrm{~s}\end{array}$ \\
\hline Slow phasic contraction & & $1(16)$ & $\begin{array}{l}\text { Wave peak with rate of pressure increase } \\
\text { between } 1 \text { and } 4 \mathrm{mmHg} / \mathrm{sec}\end{array}$ \\
\hline
\end{tabular}

MMC, Migrating motor complex.

one study characterized it as a 10 -min period with no more than 3 single contractions greater than $15 \mathrm{mmHg}$ (28), while another described it as a period of motor quiescence except for occasionally occurring isolated pressure peaks over a period of $<3 \min (31)$.

Variability also existed in the quantitative criteria of each definition. Prolonged propagated contractions were described by most studies as a single wave with large amplitude and long duration but the minimum amplitude requirement ranged from 20 to $60 \mathrm{mmHg}(32,40)$ while the minimum duration requirement ranged from 6 to $12 \mathrm{~s}(40,46)$. In view of this variability, summary definitions were derived and displayed in Table 2. The definitions shown are a combination of the most common and more inclusive criteria observed in the published studies.

There were motility terms which only featured in a small number of studies. Examples included "Migrating Clustered Contractions" (46), "Propagated Contractions" (35), "Large Pressure Waves" (48), and "Propagating Sequence" (4, 26, 27). Their definitions were similar to the main motility terms listed above. Therefore, in the review analysis, they were considered together with the main terms, as shown in Table 2. Phasic contractions (and their subgroups) were entirely different patterns and were analyzed separately.

Four older studies used the terms type I, type II, type III and type IV waves $(20,23,24,44)$ which were later replaced by more modern names described above following the description of the MMC in 1969 (52). These older terms were analyzed together with their modern counterparts, as shown in Table 2.

Three studies defined the motility index as " $\log _{\mathrm{e}}$ (sum of amplitudes $\times$ number of contractions +1$)$ " $(30,39,40)$, one study described it as " $\log _{10}($ sum of amplitudes $\times$ number of peaks +1$)$ " (32), four studies used the integration of the area under the pressure tracings $(31,34,48,49)$ and one defined it as "[sum of $\log$ (amplitudes of contractions)]/number of contractions" (36).

\section{Interdigestive Motility in Healthy Individuals}

The four most commonly reported motility patterns found during fasting were the MMC, DCCs, PPCs, and phasic contractions. A summary of their parameters is displayed in Table 3. Several researchers noted that these motility patterns were a small component of the total recording period and that the predominant activity appeared to be frequent irregular contractions $(18,45)$. Some found long periods of inactivity interspersed with more active periods (49).

\section{Migrating motor complex}

The MMC (with its three phases) was an infrequent finding in the ileum. Almost half of the studies (twelve) did not present any data on phase III/MMC. One of these studies had a prolonged recording period of $24 \mathrm{~h}$ (25). Most studies detected one phase III every $1.3-3.2 \mathrm{~h}$ of recording. One researcher noted that the incidence decreased dramatically when recording occurred close to the ileocaecal junction with one phase III detected every $40 \mathrm{~h}$ in this region (45).

The mean value of the total duration of each MMC cycle in the ileum ranged from 90 to $134 \mathrm{~min}(38,46,50)$. Of the three MMC phases, phase II was found to be the longest with one study reporting a mean duration of $64 \mathrm{~min}$ (46). The mean duration of phase I ranged from 19 to $39 \mathrm{~min}(15,46)$. Phase III was generally the shortest in duration, with mean values ranging from 6.5 to 15.6 min $(15,33)$. During sleep, two studies reported shorter or absent phase II $(7,37)$. 


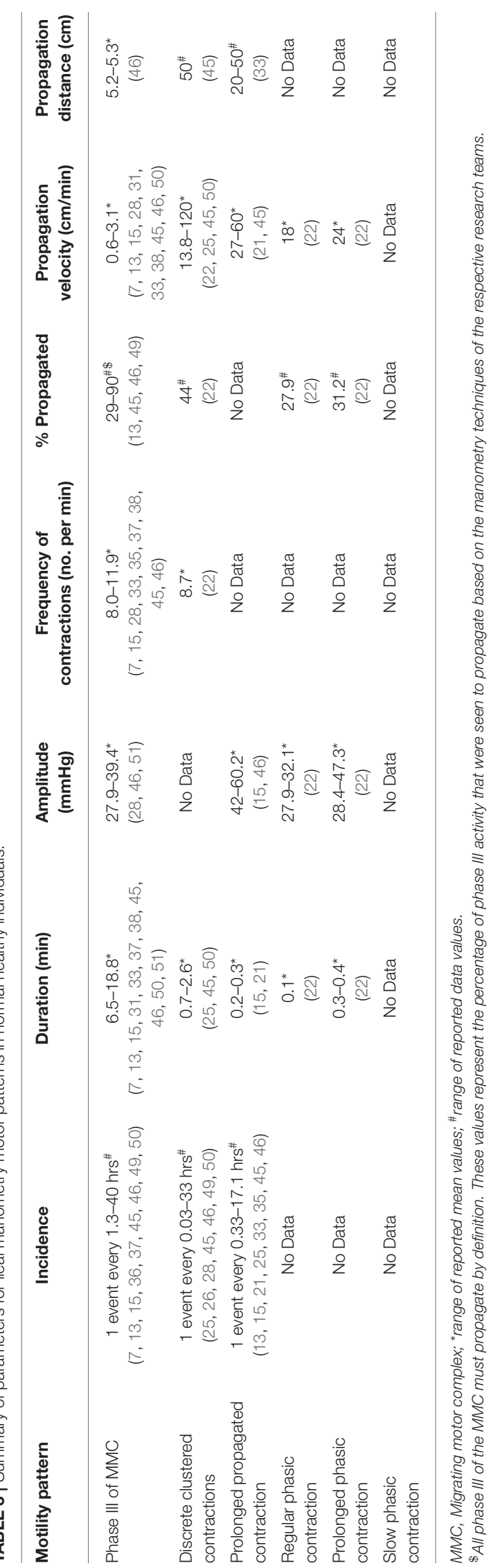

A single study reported contraction frequencies (mean of 540 waves per minute) and propagation velocities (mean of 78 $\mathrm{cm} / \mathrm{min}$ ) many orders of magnitude higher than the others (46). Given the significant discrepancy, this data was not included in the summary data table. Confirmation of data accuracy was sought via email correspondence but no response was received.

A small proportion of phase III patterns that were detected proximally in the small bowel propagated to the terminal ileum. Researchers found while $42 \%$ of MMCs propagated to the proximal ileum, only $4-9 \%$ propagated as far as the distal ileum $(15,33)$. An even smaller proportion $(2 \%)$ progressed to the ileocaecal junction (45).

To investigate the motor-flow relationship, researchers infused a non-absorbable marker, phenolsulfonphthalein, via a recording orifice of the manometry catheter assembly and then aspirated the downstream fluid (a mixture of marker and bowel content) to calculate flow based on concentration differences. They found $50 \%$ of flow occurred during phase III, $30 \%$ occurred during phase II and 20\% occurred during phase I (36). One research team found an association between phase III and ileocolonic bolus movement in only four out of nine patients (30).

\section{Discrete clustered contractions}

The majority of studies in healthy individuals (19 out of 28) did not present any data on DCCs or a similar pattern. When data was presented, the incidence was variable. Four studies found one DCC every $0.03-0.2 \mathrm{~h}$, making them much more common than the MMC in the ileum $(26,45,46,49)$. However, two studies found them to be infrequent with one DCC detected every $4-33 \mathrm{~h}$ $(25,28)$.

Discrete clustered contractions appeared to have a limited relationship with colonic motility. One study found that $15 \%$ of DCCs were associated with caecal propagating sequences while another found no relationship between DCCs and colonic filling $(25,30)$. This motor pattern was also found to have a limited role in propulsion of ileal contents, with one researcher detecting no consistent association with caudal propulsion of an isotope (49).

No studies reported data on the amplitude of DCCs in healthy individuals.

\section{Prolonged propagated contractions}

Prolonged propagated contractions were infrequent in the ileum. Twenty studies out of 28 did not present any data on PPCs or a similar pattern. One study that failed to identify this pattern had a prolonged recording period of $36 \mathrm{~h}$ (49). The majority of the studies which did detect PPCs found one event every 3.3-17.1 h $(21,46)$. Only one report found a higher incidence in some of their study participants, detecting one event every $0.33 \mathrm{~h}(45)$.

This motility pattern appeared to be more common during sleep, as one study found the incidence of propagating events (including PPCs and DCCs) were three times higher during the nocturnal period compared to day time (25).

The association between PPCs and caecal motility was greater than DCCs. One researcher found $46 \%$ of PPCs was associated with caecal propagating sequences (25). No studies reported data on the percentage of PPCs that were propagated. 


\section{Phasic contractions}

Similar to PPCs, phasic contractions had some relationship with caecal motility. One study found 36.7 and $41 \%$ of regular phasic and prolonged phasic contractions, respectively, were associated with caecal propagating sequences (22). They also found 13.3 and $29.2 \%$ of regular and prolonged phasic contraction, respectively, directly propagated from the ileum to the caecum.

\section{Motility index}

Based on the log definition of the motility index, one researcher found the mean motility index to range from 10.11 to 10.45 (30). Those that used the area under the pressure tracing found mean values that ranged from 6.1 to $17.4 \mathrm{mmHg} \cdot \min (31,48,49)$.

\section{Post-prandial Motility in Healthy Individuals}

After ingestion of food, most researchers found replacement of the interdigestive motility patterns, such as the MMC, with intense contractions that appeared irregular and failed to meet the definition criteria of any known motility patterns $(12,33,37$, $45,49,50)$. There was also an absence of other fasting patterns such as DCCs and PPCs $(45,50)$. If an MMC was detected at the start of the meal, eating interrupted further progression of that MMC (7). The onset of this post-prandial pattern was as rapid as $10 \mathrm{~min}$ after meal ingestion (50). The duration of this response ranged from 2.2 to $10.5 \mathrm{~h}(7,13,35,37,46)$. The mean motility index was significantly higher following food ingestion, with a mean value (SEM) (based on area under pressure tracings) of $23.3 \pm 2.0 \mathrm{mmHg}$.min (49). This increase was sustained for only $30 \mathrm{~min}$ before returning to fasting levels.

This abolition of interdigestive motility patterns was not found by all researchers. One study found the fasting pattern continued in 4/6 patients in one series and 5/7 in another (30). Another study found a single instance of phase III-like activity $42 \mathrm{~min}$ after a meal in one patient (37). DCC-like patterns were also noted during the post-prandial period, with one researcher reporting an incidence of one event every $13 \mathrm{~min}(27,46)$. The mean (SD) amplitude of the DCC-like pattern was reported to be $22.9 \pm 9 \mathrm{mmHg}(27)$ and the mean (SEM) propagation velocity was $84 \pm 6 \mathrm{~cm} / \mathrm{min}(46)$.

\section{Ileocaecal Junction in Healthy Individuals}

Only two studies investigated the motility patterns of the ileocaecal junction in normal individuals $(22,45)$. One researcher used an incremental pull-through technique of the manometry catheter across the ICJ introduced via colonoscopy (22) while the other used prolonged naso-enteric intubation with a perfused manometry catheter that had sensors which straddled the ICJ (45).

Both of these studies failed to identify a sustained highpressure zone in the ICJ region. One researcher found elevation of tonic pressure that was detected only during periods of sustained phasic contractions which were present less than $10 \%$ of the recording time (45). The range of pressures found was $0-$ $34 \mathrm{mmHg}$. However, not all phasic contractions elicited increase in tonic pressures at the ICJ.
Motility in Individuals With Gastrointestinal Disorders

Five studies reported manometry findings in patients with motility disorders, including chronic idiopathic constipation (13), irritable bowel syndrome $(12,28,35)$ and acute salmonellosis (15). They key similarities and differences of the manometry findings from these patients compared to normal individuals are summarized in Table 4.

\section{Irritable bowel syndrome}

One study only found a significant difference in frequency of contractions of phase III in the distal ileum (7.7 \pm 0.2 vs. $8.5 \pm 0.2$ ) but not in the proximal ileum (35). Discrete clustered contractions were noted to be infrequent in the ileum of IBS patients but no specific data were presented (28). There was suggestion that prolonged propagated contractions may be associated with abdominal pain. One study administered cholecystokinin octapeptide infusions to stimulate the small bowel and the PPCs generated were concurrent with pain in 4/5 patients with constipation-predominant IBS (12). Neostigmine injections were also given for the same purpose and the PPCs generated were concurrent with symptoms in all 7 IBS patients. Another research team found that $61 \%$ of PPCs were directly related in time to cramping discomfort in IBS patients compared to $17 \%$ in healthy controls (35). Cramping was rare in the absence of PPCs. There was no correlation between the discomfort and the magnitude of the pressure peak or propagation to the caecum.

It was unclear if this association between PPCs and abdominal discomfort was limited to IBS patients as researchers also found 4/5 healthy volunteers suffered symptoms concurrently with PPCs (12). Other studies found no association between episodes of pain and any small intestinal motility patterns (28).

\section{Acute salmonellosis}

Researchers commented on the presence of silent periods which were not found in healthy controls. This was defined as episodes of motor quiescence (with fewer than three waves over 12 $\mathrm{mmHg}$ in a 10 -min period) simultaneously recorded over two consecutive manometry sites that lasted for more than $20 \mathrm{~min}$ but did not fulfil the criteria for phase I as it was not preceded by phase III (15). These periods had a mean duration [SEM] of $64 \pm 32$ mins and affected half the length of the ileum.

\section{Motility in Individuals After Bowel Surgery}

Ten studies investigated ileal motility through either a loop or end ileostomy $(4,16,20,23,24,39-41,44,47)$. Five studies assessed the terminal ileum adjacent to an ileal pouch formed after proctocolectomy $(17,29,39,43,50)$. Two studies featured patients who had colonic exclusion for management of hepatic encephalopathy $(3,19)$ with one of these studies also featuring a patient with double-barrelled ascending colostomy for management of a pancreatic fistula (3). The key similarities and differences in manometry features compared to normal individuals are shown in Table 5.

\section{Ileostomy}

Three studies utilized manometry in only the afferent limb of a loop ileostomy $(20,23,24)$, four studies only investigated 
TABLE 4 | Summary of similarities and differences in ileal manometry features in motility disorders.

\begin{tabular}{|c|c|c|c|c|}
\hline \multirow{2}{*}{ Motility disorder } & \multicolumn{4}{|c|}{ Similarity/difference } \\
\hline & \multicolumn{3}{|c|}{ Fasting manometry features } & $\begin{array}{l}\text { Post-prandial manometry } \\
\text { features }\end{array}$ \\
\hline $\begin{array}{l}\text { Chronic idiopathic } \\
\text { constipation }\end{array}$ & $\begin{array}{l}\text { Similarities: } \\
\text { Phase III: Incidence }(1 \text { every } 3.4 \mathrm{~h})^{\$} \text { and } \\
\text { propagation velocity }(0.9 \pm 0.4 \mathrm{~cm} / \mathrm{min})^{\#}(13) \\
\text { Differences: } \\
\text { Phase II: Longer duration }(54.1 \pm 8.5 \% \text { of } \\
\text { total recording period vs. } 8.2 \pm 2.1 \% \text { in } \\
\text { controls) })^{\# *}(13) \\
\text { Phase III: Shorter duration }(7.9 \pm 1.8 \text { mins vs. } \\
13.2 \pm 1.3 \text { min in controls) })^{\# ~ * ~(13) ~} \\
\text { Phase III: Smaller percentage propagating (62 } \\
\text { vs. } 90 \%)^{\$}(13) \\
\text { Phase III: Retrograde propagation more } \\
\text { common (11 instances vs. none in control } \\
\text { group) })^{\$}(13)\end{array}$ & No Data & $\begin{array}{l}\text { Differences: Incidence: Lower (1 } \\
\text { event every } 12 \mathrm{~h} \text { vs. } 1 \text { even every } \\
4 \mathrm{~h} \text { in controls) })^{\# \star}(13)\end{array}$ & $\begin{array}{l}\text { Differences: Duration of response: } \\
\text { Shorter }(30.1 \pm 6.2 \mathrm{~min} \text { vs. } 130 \pm \\
68 \mathrm{~min} \text { in controls })^{\# \star}(13)\end{array}$ \\
\hline $\begin{array}{l}\text { Irritable bowel } \\
\text { syndrome }\end{array}$ & $\begin{array}{l}\text { Similarities: } \\
\text { Phase III: Duration, frequency of contractions } \\
(7.7-10.1 \text { per minute) })^{\&} \text {, amplitude }(41.6 \pm 1.5 \\
\mathrm{mmHg})^{\#} \text {, propagation velocity }(2.9 \pm 0.2 \\
\mathrm{cm} / \mathrm{min})^{\#}(28) \\
\text { Differences: } \\
\text { Phase III: Higher proportion migrating to distal } \\
\text { ileum (26 vs. } 9 \% \text { in controls) })^{\$}(35)\end{array}$ & No Data & $\begin{array}{l}\text { Similarities: Incidence (1 every } \\
3.6-8.8 \mathrm{~h})^{\$}(35)\end{array}$ & $\begin{array}{l}\text { Similarities: } \\
\text { Duration of response }(12,35) \\
\text { Replacement of MMCs with random, } \\
\text { irregular contractions }(12,35)\end{array}$ \\
\hline $\begin{array}{l}\text { Acute } \\
\text { salmonellosis }\end{array}$ & $\begin{array}{l}\text { Similarities: } \\
\text { Phase III: Duration }(7.5 \pm 2.3 \mathrm{~min})^{\#} \text {, } \\
\text { propagation velocity }(2.5 \pm 1.3 \mathrm{~cm} / \mathrm{min})^{\#} \text {, and } \\
\text { percentage propagating into ileum }(37 \%)^{\$} \text { (15) } \\
\text { Differences: Phase III: Lower incidence }(1 \\
\text { event every } 5.5 \mathrm{~h} \text { vs. } 1 \text { event every } 1.6 \mathrm{~h})^{\$}(15)\end{array}$ & No Data & $\begin{array}{l}\text { Similarities: } \\
\text { Duration }(0.23 \pm 0.03 \mathrm{~min})^{\#} \text { and } \\
\text { amplitude }(48 \pm 4 \mathrm{mmHg})^{\#}(15) \\
\text { Differences: } \\
\text { Incidence: Higher (1 event every } \\
1.3 \mathrm{~h} \text { vs. } 1 \text { event every } 6.7 \mathrm{~h})^{\$} \\
\text { (15) } \\
\text { Propagation velocity: Higher } \\
\text { (mean } 156 \mathrm{~cm} / \mathrm{min})(15)\end{array}$ & No Data \\
\hline
\end{tabular}

MMC, Migrating Motor Complex; PPC, Prolonged Propagated Contraction; DCC, Discrete Clustered Contractions; \#mean \pm SEM.

*Statistically significant difference $(p<0.05)$, $\$$ reported values, \& range of reported means.

the efferent limb $(16,39-41)$ and one research team measured motility in both limbs (4). No direct comparisons between motility of the afferent and efferent limbs were made. One study featured end ileostomies (16) while two studies did not specify which limb was assessed $(44,47)$.

Only one study identified phase III complexes, which included a pediatric population only (47). Their predominant finding was that of irregular, intermittent contractions. The characteristics of the detected motility patterns were similar to those found in normal adults.

The duration of regular and prolonged phasic contractions were similar (16). The mean amplitudes of regular and prolonged phasic contractions (36-37 and 58-59 $\mathrm{mmHg}$, respectively) were higher than the values seen in normal individuals (16). There appeared to be a smaller percentage of regular phasic contractions that propagated (4-12.5\%). The propagation velocity of regular phasic contractions appeared to be higher, with a mean of $30 \mathrm{~cm} / \mathrm{min}$. The motility index, based on the $\log$ definition, appeared slightly lower with mean values ranging from 8.1 to $10.0(39,40)$.

Researchers reported data for which there were no corresponding values in normal individuals to allow comparison. This included the mean amplitude of DCC [15.5-68.0 $\mathrm{mmHg}$ $(4,39)]$, the percentage of PPCs found to propagate $[85 \%$ $(39,40)]$, and the mean frequency of contractions of regular phasic contractions $[7.0-8.6$ per minute $(16,20)]$. Slow phasic contractions were found to have a mean duration of $18-20 \mathrm{~s}$, a mean amplitude of $23-24 \mathrm{mmHg}$ and $6-20 \%$ of contractions were found to propagate (16). The same study also showed $36.7-64.3 \%$ of phasic contractions were associated with caecal motor activity.

Three studies used the ileostomy as an access point for investigating the ICJ $(4,16,41)$. There were inconsistent findings. One researcher was able to identify a region of sustained increased tone with a mean (SEM) pressure of $9.7 \pm 3.2 \mathrm{mmHg}$ and a mean length of $4.8 \mathrm{~cm}$ (4). However, one study failed to identify a discrete high-pressure zone while another only detected 
TABLE 5 | Summary of similarities and differences in ileal manometry features in bowel surgery patients.

\begin{tabular}{|c|c|c|c|c|}
\hline \multirow[b]{3}{*}{ Surgical procedure } & \multicolumn{4}{|c|}{ Similarity/difference } \\
\hline & \multicolumn{3}{|c|}{ Fasting manometry features } & \multirow{2}{*}{$\begin{array}{l}\text { Post-prandial manometry } \\
\text { features }\end{array}$} \\
\hline & MMC & DCC & PPC & \\
\hline lleostomy & $\begin{array}{l}\text { Similarities: Phase III: Frequency of } \\
\text { contractions ( } 8 \text { per minute) })^{\#} \text { and } \\
\text { propagation velocity }(2.5 \mathrm{~cm} / \mathrm{min})^{\#} \\
(47)\end{array}$ & $\begin{array}{l}\text { Similarities: } \\
\text { Incidence }(1 \text { every } 0.2-2.5 \mathrm{~h})^{\# \$} \\
\text { and propagation velocity }(11.7 \\
\mathrm{cm} / \text { min })^{\$}(4,39,40) \\
\text { Differences: } \\
\text { Duration: Shorter }(0.1 \text { to } \\
1.5 \text { min })^{\$}(4,20) \\
\text { Percentage propagated: Lower } \\
(28 \%)^{\#}(39) \\
\text { Retrograde DCCs }(46 \% \text { of } \\
\text { DCCs) }{ }^{\#}(39)\end{array}$ & $\begin{array}{l}\text { Similarities: Incidence }(1 \\
\text { every } 0.9-1.7 \mathrm{~h})^{\#}(39,40)\end{array}$ & 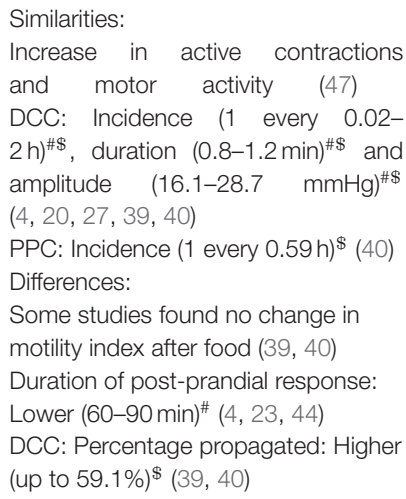 \\
\hline $\begin{array}{l}\text { Proctocolectomy with } \\
\text { Ileo-anal Pouch }\end{array}$ & $\begin{array}{l}\text { Similarities: } \\
\text { Phase III: Incidence during daytime in } \\
\text { patients with poor pouch function (1 } \\
\text { every } 1.88 \mathrm{~h})^{\& *}(29) \\
\text { Phase III: Duration (6-10 min) }{ }^{\$ \&} \\
(29,50) \\
\text { Phase III: Tend to fade out in terminal } \\
\text { ileum }(29,50) \\
\text { Differences: } \\
\text { Phase I: Duration: Longer } \\
\text { (49-80 min)\& (29) } \\
\text { Phase III: Incidence in evening: Higher } \\
\text { in patients with poor pouch function* } \\
\text { (1 event every 0.88 h)\& (29) } \\
\text { Phase III: Propagation velocity: Higher } \\
\text { (up to } 7 \mathrm{~cm} / \mathrm{min} \text { ) \& }(29,50)\end{array}$ & $\begin{array}{l}\text { Similarities: } \\
\text { Duration }(0.7 \mathrm{~min})^{\$} \text { and } \\
\text { propagation velocity }(116 \\
\mathrm{cm} / \mathrm{min})^{\$}(50) \\
\text { Differences: } \\
\text { Incidence: Higher in patients with } \\
\text { poor pouch function (1 event } \\
\text { every } 0.5 \mathrm{~h})^{\&}(29)\end{array}$ & $\begin{array}{l}\text { Similarities: Incidence }(1 \\
\text { every } 0.08-2.7 \mathrm{~h})^{\#}(17,50)\end{array}$ & $\begin{array}{l}\text { Similarities: } \\
\text { Intense, random contractions (50) } \\
\text { Duration of response }(73-360 \mathrm{~min})^{\#} \\
(29,50) \\
\text { Rapid onset of response (within } \\
10 \mathrm{~min})^{\#}(50) \\
\text { Absence of PPCs and DCCs (50) } \\
\text { Differences: } \\
\text { Persistence of fasting motility pattern } \\
\text { in one study (17) }\end{array}$ \\
\hline
\end{tabular}

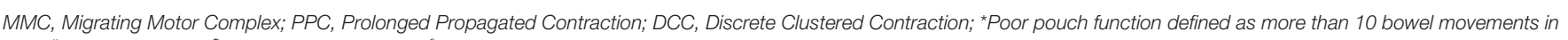
$24 \mathrm{~h}$, " Reported values, ${ }^{\$}$ Reported mean values, \& Reported median values.

an increase in tone associated with increased phasic activity at the ICJ $(16,41)$. This phasic activity had a frequency of contraction of 4-8 per minute and was present during a mean of $35 \%$ of fasting recording time (4). Ileal propagating wave patterns had primarily an inhibitory effect on phasic and tonic activity at the ICJ and all such wave patterns which extended through the ICJ to the caecum did so only when phasic activity was absent in the region (4).

The effects of ileal and colonic distension on ICJ tone were also investigated. Colonic distension produced an increase in tone (mean of $2.8-3.5 \mathrm{mmHg}$ ). This increase affected both the afferent and efferent ileal limbs (4). However, ileal distension produced mixed results with one researcher finding a mean decrease in ICJ tone of $2.8 \mathrm{mmHg}$, while another found instances of increased, decreased and unchanged ICJ tone $(4,41)$. The effects of distension on phasic activity were also noted. Colonic distension produced either an increase (mean difference of $7.4 \mathrm{mmHg}$ ) or no change to the amplitude of phasic waves. The duration of phasic activity also increased from a mean of $17 \%$ of total recording period to $55 \%$ (41). Ileal distension produced opposite effects, with a mean decrease in phasic wave amplitude of $5.9 \mathrm{mmHg}$ and a decrease in the duration from 60 to $15 \%$ of the recording time. This was not the case in all instances as $4 \%$ of ileal distension episodes produced an increase in phasic activity and $20 \%$ of distensions produced no change (41).

In the post-prandial period, one research team noted an immediate increase in ICJ tone with a mean pressure of $11.8 \mathrm{mmHg}$ that was sustained for $90 \mathrm{~min}$. Following this time period, the tone reduced down to a mean of 4.9 mmHg, which was lower than the fasting value (4). After food ingestion, retrograde propagation was found in $41-50 \%$ of propagated DCCs. One researcher noted the amplitude of regular phasic contractions increased after eating (24). The amplitude of prolonged phasic contractions appeared to be lower $(11.0 \mathrm{mmHg})$ than fasting values (24). The frequency of contractions of regular phasic contractions (6.6-7.9 per minute) was slightly lower than fasting values in normal individuals (20). 


\section{Proctocolectomy}

Five studies investigated patients with proctocolectomy with ileal-anal anastomosis. The specific procedures performed were ileal pouch-anal canal anastomosis with diverting loop ileostomy (39), ileal pouch-anal canal anastomosis after reversal of the loop ileostomy $(29,50)$, ileal pouch-anal canal anastomosis with no specific history of diverting ileostomy (17) and pelvic ileoanal reservoir with a short efferent ileal limb between the pouch and anal canal (43).

One study failed to identify phase III (17). The duration of phase II was found to have a median value of $4-7 \mathrm{~min}$. This parameter was not reported in studies of normal individuals (29). Discrete clustered contractions were reported to be the dominant pattern in the ileum in one study, with the majority being nonmigratory (39). There was a particularly high incidence of PPCs in patients who complained of frequent stools, with one event every $0.08-0.2 \mathrm{~h}$ (17). The range of PPC amplitude values found were between 50 and $100 \mathrm{mmHg}$ (17). After food ingestion, DCCs were only found in the late post-prandial period beyond $3 \mathrm{~h}(50)$.

Motility of the ileal pouch itself was characterized by irregular sporadic contractions (17). One study noted $<2 \%$ of all phase III complexes and none of the DCCs migrated into the pouch reservoir (29). In contrast, multiple PPCs were found to propagate into the pouch (29). The timing of bowel movements and the sensation of urge to defecate did not correlate with any motility pattern $(29,50)$. Defecation occurred in all phases of the MMC. Other researchers noted two patterns of motor activity within the pouch: short waves 2-6s in duration and long waves up to $30 \mathrm{~s}$ (43). After ingestion of food, one research team noted a two-stage effect: disorganization of phase III followed by large propulsive contractions, sometimes causing urgency (43).

Two studies investigated the effect of pouch inflation on the motility of the pouch and proximal ileum. One study found pouch distension up to functional capacity produced polyphasic pressure waves with contractions lasting $15-25 \mathrm{~s}$, with amplitudes of $14.7-22.1 \mathrm{mmHg}$ in the pouch and $44.1-51.5 \mathrm{mmHg}$ in distal limb (43). The other study found no change in motility patterns (29).

One research team focused on motility differences between patients with good pouch function and those with poor pouch function, defined by the number of bowel movements per day (29). Patients with poor function had a significantly longer period of increased activity prior to defecation ( $25 \mathrm{vs} .9 \mathrm{~min}, p=0.003$ ), a higher incidence of the MMC at night, and overall shorter duration of motor quiescence (phase I). All other parameters including duration of $\mathrm{MMC}$, incidence of $\mathrm{MMC}$ during the day time, incidence of DCCs and PPCs and the duration of the post-prandial response were similar. Another study found that ileal pouch patients with excessive stools had frequent nonpropagated high amplitude contractions within the pouch that was often accompanied by defecation (17).

\section{Colonic exclusion}

Two studies evaluated patients who had undergone colonic exclusion procedures. In both studies, the procedure left patients with an ileostomy in the right lower quadrant $(3,19)$. One researcher also included a patient with a double-barrelled ascending colostomy (3). These investigations focused on the ICJ region only.

Both of these studies found a discrete high-pressure zone at the ICJ with a length of $4 \mathrm{~cm}$ and a mean pressure of 20.3-21 $\mathrm{mmHg}(3,19)$. Distension of the caecum was found to cause a mean increase in the ICJ tone of $17 \mathrm{mmHg}$ while distension of the ileum caused a mean decrease of $12 \mathrm{mmHg}$ (3). These effects were present during 80 and $87 \%$ of colonic and ileal distension episodes, respectively. The change in tone occurred rapidly after a mean of $2.3 \mathrm{~s}$ following distension and the duration of the change was correlated directly with the length of balloon distension.

\section{DISCUSSION}

\section{Summary of Main Findings}

This study reports a systematic review summarizing the current knowledge of human ileum and ICJ manometry findings in the context of health, motility disorders or after bowel surgery during both fasting and fed states. The motility in health demonstrated distinct patterns during fasting compared to the post-prandial period. While fasted, the main patterns found were the MMC and its three phases, DCCs, PPCs, and phasic contractions. DCCs appeared to be the most common with MMC phase III being the rarest. However, the incidences of these patterns were highly variable (as per Table 3). Phase III of the MMC had the longest duration lasting for several minutes, whereas DCCs, PPCs and phasic contractions often lasted $<1 \mathrm{~min}$. A large proportion of phase III activity appeared to propagate (based on the available manometry techniques) but at slower velocities compared to the other patterns. Almost half of all DCCs propagated while less than a third of regular and prolonged phasic contractions propagated. Prolonged propagated contractions appeared to have the highest amplitude of any pattern. During the post-prandial period, these patterns became much harder to detect and the predominant finding was intense, irregular contractions, which persisted for 3-4 h.

The functional significance of these patterns has been evaluated and theorized. Phase III of the MMC is thought to clear the luminal contents and act as the intestinal "housekeeper" (53). As PPCs were found to be triggered by infusing short chain fatty acids into the ileum, they may protect against coloileal reflux (32). Findings from animal studies support these theories. Each passage of phase III of the MMC in the canine ileum is associated with emptying of half of luminal contents into the colon and instillation of short chain fatty acids into the ileum of animal models also triggered PPCs which cleared refluxate from the colon (54-57). However, given the rarity and often complete absence of these two motility patterns in the human ileum, their importance in this region is unclear.

There were inconsistent findings regarding the ICJ. Some researchers found a $4 \mathrm{~cm}$ segment of sustained increased tonic pressure while others did not $(22,45)$. When such a segment was found, the mean pressure detected ranged from 9.7 to 21 $\mathrm{mmHg}$. The pressure of the ICJ region was comprised of both a tonic component as well as phasic activity, present for up to $35 \%$ of the recording period (4). Experimental distension of the colon tended to produce an increase in the ICJ tone while 
distension of the ileum produced a decrease in ICJ tone, but this was inconsistent. The variable response of the ICJ to colonic distension may partially explain why up to $25 \%$ of the population are thought to have an incompetent ileocaecal valve but further targeted studies are required to confirm this (58).

Although studies were limited, manometry findings in patients with motility disorders differed from healthy controls in a few aspects. Patients with chronic idiopathic constipation had longer duration of phase II and phase III, lower incidence of PPCs, and shorter duration of post-prandial response (13). Patients with IBS had significantly lower frequency of contractions of phase III and PPCs tended to have a stronger association with abdominal pain symptoms, although this was inconsistent. Acute Salmonellosis patients had "silent periods" with little motor activity that lasted for more than an hour which was not seen in healthy controls (15).

Bowel surgery patients also demonstrated differences in manometry findings compared to healthy controls. In patients with an ileostomy, researchers found retrograde DCCs, higher amplitude of regular and prolonged phasic contractions, and higher propagation velocity of regular phasic contractions. However, none of the ileostomy studies were case controlled. Data collected exclusively from the efferent limb did not reveal any notable differences compared to data from the afferent limb between the studies. Only one researcher placed manometry catheters into both the afferent and efferent limbs of a loop ileostomy in the same patient but no direct comparisons were made (4).

Patients who had proctocolectomy with ileal pouches showed a longer duration of phase I compared to healthy controls. Comparison between those with good pouch function and poor function showed a significantly longer period of increased activity prior to defecation, higher incidence of MMC at night and shorter duration of phase I in those with poor function. Studies involving colonic exclusion patients focused on the ICJ only and identified a discrete high-pressure zone of $4 \mathrm{~cm}$ in length.

The motility characteristics of healthy individuals exhibited significant variability and this wide variation appears to limit the ability of ileal manometry to readily distinguish pathological motility from normal motility. Analysis of data from patients with motility disorders, e.g., IBS, and patients who underwent bowel surgery, e.g., loop ileostomy, in this systematic review found few major differences in motility patterns. This variability may be a true intrinsic feature of human ileal motility but two factors that may confound interpretations are the difficulties of manometry equipment and the lack of standard definitions.

\section{Limitations}

Accurate assessment of the terminal ileum using manometry is challenging. As shown in Table 1, researchers employed a variety of manometry techniques with different catheter specifications and protocols. Each of these details could potentially influence motility measurement. For example, a stiff manometry catheter with a large diameter could lead to higher pressures recorded $(4,46)$. Large spacing, e.g., $20 \mathrm{~cm}$, between sensors could reduce the sensitivity for detecting propagation, which may lead to some instances of phase III with short migration after reaching the ileum being missed or wrongly classified (15). A long manometry catheter introduced via oral or nasal route could induce sleeving of the small intestine over the catheter which would underestimate propagation velocities (28). The viscosity of luminal contents can also alter manometry measurements (59). Short recording durations may fail to detect motility patterns due to their low incidence (47). A low caloric content of the ingested meal during the experiments may not be sufficient to trigger a motility response in the ileum (30). Restrictions placed on study participants during recording, e.g., limitations on mobility, prolonged starvation, and being in a foreign environment, may induce stress which is known to affect small bowel motility, especially in IBS patients (28).

Manometry assessments of an ileal pouch could be confounded by the pouch construction itself. When walls of large-volume, low-pressure reservoirs contract, this may not translate to an accurate rise in intra-luminal pressure detected by manometry. This limitation could account for the lower motility index and fewer cluster contractions detected in the included studies (40).

The ileocaecal junction is relatively inaccessible and dynamic, creating difficulties in precise positioning of manometry sensors. For example, a long nasoenteric manometry catheter with widely spaced sensors does not allow for the accurate placement and maintenance of a sensor within the relatively short segment of the ICJ. Using bowel preparation to allow placement of a manometry catheter via colonoscopy as well as the caecal distension (which studies in this review has shown could alter the ICJ pressure profile) from the colonoscope could also confound ICJ motility findings $(22,41,45)$. However, one researcher directly compared ICJ recording using endoscopy to a trans-ileostomy approach and found similar results (16).

A significant problem is the lack of accepted standard definitions of ileal motility patterns. Up to 18 studies described phase III, DCCs and PPCs and there was little agreement of the defining characteristics. The low incidence of these patterns reported in some studies may be due to strict definition criteria that the observed manometry patterns failed to meet. The same manometry findings may have fulfilled the criteria for a particular term of a different research team. Therefore, inconsistent definitions weaken the ability to make meaningful comparisons across studies.

Accurate assessment of ileal motility may be of benefit to patients who have undergone bowel surgery, such as loop ileostomy. Common complications following ileostomy reversal include small bowel obstruction and prolonged post-operative ileus with rates as high as $20 \%(60)$. Histology studies have demonstrated villous atrophy and reduction in the strength and duration of circular smooth muscle contractions in the distal ileal limb following a period of faecal diversion (6163). It is plausible that this loss of contractility may lead to a "functional" obstruction at time of ileostomy reversal resulting in the aforementioned complications. The loop ileostomy is thus not only an easy access point but also an area where greater understanding of motility could inform improved post-operative outcomes. No studies found in this review directly compared efferent limb motility to healthy controls or to the afferent limb. 
Manometry studies involving such comparisons may help to assess the effects of faecal diversion on bowel motility.

Future research into ileal motility must attempt to optimize elements of manometry technique and study protocol. Recording should occur over a prolonged period of fasting to allow detection of infrequent patterns, i.e., at least $3 \mathrm{~h}$. If prolonged day-time recording is planned, eating three meals a day will likely lead to absence of motility phenomena given the abolition of the MMC in the post-prandial period. Reducing the inter-sensor spacing would provide better characterization of pattern propagation (64). When assessing the ICJ, effort should be made to accurately confirm sensor placement and utilization of ileostomies could be a safe, convenient and effective method. Studies should strive to use manometry pattern definitions either from extant literature with similar investigative focus or the summary definitions in this review to provide better consistency and avoid creating further new definitions.

Contradictory data exists regarding the effect of food ingestion on fasting motility, the presence or absence of a discrete high-pressure zone at the ICJ, the effect on the ICJ of ileal distension and associations between PPCs and abdominal discomfort in IBS patients. Further studies focused on addressing these inconclusive aspects of ileal motility whilst being mindful of the above measurement and protocol issues could be beneficial.

Consideration should be given to the establishment of an international and interdisciplinary consensus group to help formulate standardized operation protocols. Manometry pattern definitions can also be agreed upon and such a group could also assist with co-ordination of a multi-center approach to recruitment and data collection to increase study power.

\section{REFERENCES}

1. Li T, Chiang JY. Bile acids as metabolic regulators. Curr Opin Gastroenterol. (2015) 31:159-65. doi: 10.1097/MOG.0000000000000156

2. Kozyraki R, Cases O. Vitamin B12 absorption: mammalian physiology and acquired and inherited disorders. Biochimie. (2013) 95:1002-7. doi: 10.1016/j.biochi.2012.11.004

3. Cohen S, Harris LD, Levitan R. Manometric characteristics of the human ileocecal junctional zone. Gastroenterology. (1968) 54:72-5. doi: 10.1016/S0016-5085(68)80040-X

4. Dinning PG, Bampton PA, Kennedy ML, Kajimoto T, Lubowski DZ, De Carle DJ, et al. Basal pressure patterns and reflexive motor responses in the human ileocolonic junction. Am J Physiol Gastrointest Liver Physiol. (1999) 276:G331-40. doi: 10.1152/ajpgi.1999.276.2.G331

5. Christl SU, Scheppach W. Metabolic consequences of total colectomy. Scand J Gastroenterol Suppl. (1997) 222:20-4. doi: 10.1080/00365521.1997.117 20712

6. Gorbach SL, Plaut AG, Nahas L, Weinstein L, Spanknebel G, Levitan R. Studies of intestinal microflora. II. Microorganisms of the small intestine and their relations to oral and fecal flora. Gastroenterology. (1967) 53:856-67. doi: 10.1016/S0016-5085(19)34122-8

7. Kerlin P, Phillips S. Variability of motility of the ileum and jejunum in healthy humans. Gastroenterology. (1982) 82:694-700. doi: 10.1016/0016-5085(82)90313-4

8. Vantrappen G, Janssens J, Hellemans J, Ghoos Y. The interdigestive motor complex of normal subjects and patients with bacterial overgrowth of the small intestine. J Clin Invest. (1977) 59:1158-66. doi: 10.1172/JCI108740

\section{Conclusions}

Manometry recording of the terminal ileum in health shows different motility patterns during fasting compared to the post-prandial period. There exists large variability of pattern characteristics in health. The exact motility pattern of the ileocaecal junction is inconclusive with conflicting findings. Motility patterns show some differences in patients with motility disorders and bowel surgery, however technical challenges and lack of standardized definitions impair researchers' abilities to accurately assess this critical region of the gastrointestinal tract. Future research is warranted with careful attention to the influence of manometry technique and study protocol.

\section{DATA AVAILABILITY STATEMENT}

The raw data supporting the conclusions of this article will be made available by authors, without undue reservation, to any qualified researchers.

\section{AUTHOR CONTRIBUTIONS}

CL, IB, and GO'G contributed to the design of the protocol. CL and KS performed the literature search. CL extracted the data. KS checked data accuracy. CL, GO'G, PD, and IB contributed toward the writing and editing of the manuscript.

\section{FUNDING}

The lead author, CL, was supported by a research grant from the University of Auckland. GO'G and IB are supported by the NZ Health Research Council.
9. Rees WD, Leigh RJ, Christofides ND, Bloom SR, Turnberg LA. Interdigestive motor activity in patients with systemic sclerosis. Gastroenterology. (1982) 83:575-80. doi: 10.1016/S0016-5085(82)80192-3

10. Nowak TV, Anuras S, Brown BP, Ionasescu V, Green JB. Small intestinal motility in myotonic dystrophy patients. Gastroenterology. (1984) 86(5 Pt 1):808-13.

11. Cucchiara S, Annese V, Minella R, Franco MT, Iervolino C, Emiliano M, et al. Antroduodenojejunal manometry in the diagnosis of chronic idiopathic intestinal pseudoobstruction in children. J Pediatr Gastroenterol Nutr. (1994) 18:294-305. doi: 10.1097/00005176-199404000-00008

12. Kellow JE, Phillips SF, Miller LJ, Zinsmeister AR. Dysmotility of the small intestine in irritable bowel syndrome. Gut. (1988) 29:1236-43. doi: 10.1136/gut.29.9.1236

13. Panagamuwa B, Kumar D, Ortiz J, Keighley MRB. Motor abnormalities in the terminal ileum of patients with chronic idiopathic constipation. Br J Surg. (1994) 81:1685-8. doi: 10.1002/bjs.1800811142

14. Liberati A, Altman DG, Tetzlaff J, Mulrow C, Gotzsche PC, Ioannidis JP, et al. The PRISMA statement for reporting systematic reviews and meta-analyses of studies that evaluate healthcare interventions: explanation and elaboration. BMJ. (2009) 339:b2700. doi: 10.1136/bmj.b2700

15. Accarino AM, Azpiroz F, Malagelada JR. Distinctive motor responses to human acute salmonellosis in the jejunum and ileum. J Gastrointest Motil. (1993) 5:23-31. doi: 10.1111/j.1365-2982.1993.tb00104.x

16. Barberani F, Corazziari E, Tosoni M, Badiali D, Materia E, Ribotta G, et al. Perendoscopic manometry of the distal ileum and ileocecal junction: technique, normal patterns, and comparison with transileostomy manometry. Gastrointest Endosc. (1994) 40:685-91. doi: 10.1016/S0016-5107(94)70110-5 
17. Bassotti G, Castagnoli G, Trancanelli V, Pelli MA, Morelli A. Patients with ileal pouch-anal anastomosis display contractile abnormalities of the reservoir and of the upper lleum. Dig Surg. (1991) 8:10-4. doi: 10.1159/000171987

18. Borody TJ, Quigley EM, Phillips SF, Wienbeck M, Tucker RL, Haddad A, et al. Effects of morphine and atropine on motility and transit in the human ileum. Gastroenterology. (1985) 89:562-70. doi: 10.1016/0016-5085(85)90452-4

19. Castell DO, Cohen S, Harris LD. Response of human ileocecal sphincter to gastrin. Am J Physiol. (1970) 219:712-5. doi: 10.1152/ajplegacy.1970.219.3.712

20. Code CF, Rogers AG, Schlegel J, Hightower NC Jr, Bargen JA. Motility patterns in the terminal ileum; studies on two patients with ulcerative colitis and ileac stomas. Gastroenterology. (1957) 32:651-65. doi: 10.1016/S0016-5085(57)80061-4

21. Coffin B, Lemann M, Flourie B, Picon L, Rambaud JC, Jian R. Ileal tone in humans: effects of locoregional distensions and eating. Am J Physiol Gastrointest Liver Physiol. (1994) 267:G569-74. doi: 10.1152/ajpgi.1994.267.4.G569

22. Corazziari E, Barberani F, Tosoni M, Boschetto S, Torsoli A. Perendoscopic manometry of the distal ileum and ileocecal junction in humans. Gastroenterology. (1991) 101:1314-9. doi: 10.1016/0016-5085(91)90082-V

23. Cummins AJ. Small intestinal function in patients with an ileostomy. Am J Med. (1954) 16:237-45. doi: 10.1016/0002-9343(54)90340-X

24. Daniel EE, Sutherland WH, Bogoch A. Effects of morphine and other drugs on motility of the terminal ileum. Gastroenterology. (1959) 36:510-23. doi: 10.1016/S0016-5085(59)80075-5

25. Dinning PG, Bampton PA, Kennedy ML, Cook IJ. Relationship between terminal ileal pressure waves and propagating proximal colonic pressure waves. Am J Physiol Gastrointest Liver Physiol. (1999) 277:G983-92. doi: 10.1152/ajpgi.1999.277.5.G983

26. Dinning PG, Szczesniak M, Cook IJ. Removal of tonic nitrergic inhibition is a potent stimulus for human proximal colonic propagating sequences. Neurogastroenterol Motil. (2006) 18:37-44. doi: $10.1111 / j .1365-2982.2005 .00724 . x$

27. Dinning PG, Szczesniak MM, Cook IJ. Determinants of postprandial flow across the human ileocaecal junction: a combined manometric and scintigraphic study. Neurogastroenterol Motil. (2008) 20:1119-26. doi: $10.1111 / j .1365-2982.2008 .01145 . x$

28. Gorard DA, Libby GW, Farthing MJ. Ambulatory small intestinal motility in 'diarrhoea' predominant irritable bowel syndrome. Gut. (1994) 35:203-10. doi: 10.1136/gut.35.2.203

29. Groom JS, Kamm MA, Nicholls RJ. Relationship of small bowel motility to ileoanal reservoir function. Gut. (1994) 35:523-9. doi: 10.1136/gut.35.4.523

30. Hammer J, Camilleri M, Phillips SF, Aggarwal A, Haddad AM. Does the ileocolonic junction differentiate between solids and liquids? Gut. (1993) 34:222-6. doi: 10.1136/gut.34.2.222

31. Kachel G, Ruppin H, Hagel J, Barina W, Meinhardt M, Domschke W. Human intestinal motor activity and transport: effects of a synthetic opiate. Gastroenterology. (1986) 90:85-93. doi: 10.1016/0016-5085(86)90079-X

32. Kamath PS, Phillips SF, Zinsmeister AR. Short-chain fatty acids stimulate ileal motility in humans. Gastroenterology. (1988) 95:1496-502. doi: 10.1016/S0016-5085(88)80068-4

33. Kellow JE, Borody TJ, Phillips SF, Tucker RL, Haddad AC. Human interdigestive motility: variations in patterns from esophagus to colon. Gastroenterology. (1986) 91:386-95. doi: 10.1016/0016-5085(86)90573-1

34. Kellow JE, Miller LJ, Phillips SF, Haddad AC, Zinsmeister AR, Charboneau JW. Sensitivities of human jejunum, ileum, proximal colon, and gallbladder to cholecystokinin octapeptide. Am J Physiol. (1987) 252(3 Pt 1):G345-56. doi: 10.1152/ajpgi.1987.252.3.G345

35. Kellow JE, Phillips SF. Altered small bowel motility in irritable bowel syndrome is correlated with symptoms. Gastroenterology. (1987) 92:1885-93. doi: 10.1016/0016-5085(87)90620-2

36. Kerlin P, Zinsmeister A, Phillips S. Relationship of motility to flow of contents in the human small intestine. Gastroenterology. (1982) 82:701-6. doi: 10.1016/0016-5085(82)90314-6

37. Kerlin P, Zinsmeister A, Phillips S. Motor responses to food of the ileum, proximal colon, and distal colon of healthy humans. Gastroenterology. (1983) 84:762-70. doi: 10.1016/0016-5085(83)90144-0

38. Luiking YC, Akkermans LM, van der Reijden AC, Peeters TL, van Berge-Henegouwen GP. Differential effects of motilin on interdigestive motility of the human gastric antrum, pylorus, small intestine and gallbladder. Neurogastroenterol Motil. (2003) 15:103-11. doi: 10.1046/j.1365-2982.2003.00395.x

39. Miedema BW, Karlstrom L, Hanson RB, Johnson GP, Kelly KA. Absorption and motility of the bypassed human ileum. Dis Colon Rectum. (1990) 33:82935. doi: 10.1007/BF02051917

40. Miedema BW, Köhler L, Smith CD, Phillips SF, Kelly KA. Preoperative perfusion of bypassed ileum does not improve postoperative function. Dig Dis Sci. (1998) 43:429-35. doi: 10.1023/A:1018887212921

41. Nasmyth DG, Williams NS. Pressure characteristics of the human ileocecal region-a key to its function. Gastroenterology. (1985) 89:345-51. doi: 10.1016/0016-5085(85)90335-X

42. Penagini R, Spiller RC, Misiewicz JJ, Frost PG. Effect of ileal infusion of glycochenodeoxycholic acid on segmental transit, motility, and flow in the human jejunum and ileum. Gut. (1989) 30:609-17. doi: 10.1136/gut.30.5.609

43. Pescatori M. Myoelectric and motor activity of the terminal ileum after pelvic pouch for ulcerative colitis. Dis Colon Rectum. (1985) 28:246-53. doi: 10.1007/BF02554045

44. Posey EL Jr, Bargen JA. Observations of normal and abnormal human intestinal motor function. Am J Med Sci. (1951) 221:10-20. doi: 10.1097/00000441-195101000-00003

45. Quigley EMM, Borody TJ, Phillips SF, Wienbeck M, Tucker RL, Haddad A. Motility of the terminal ileum and ileocecal sphincter in healthy humans. Gastroenterology. (1984) 87:857-66. doi: 10.1016/0016-5085(84)9 0080-5

46. Seidl H, Gundling F, Pfeiffer A, Pehl C, Schepp W, Schmidt T. Comparison of small-bowel motility of the human jejunum and ileum. Neurogastroenterol Motil. (2012) 24:e373-80. doi: 10.1111/j.1365-2982.2012.01955.x

47. Sood MR, Cocjin J, Di Lorenzo C, Narasimha Reddy S, Flores AF, Hyman PE. Ileal manometry in children following ileostomies and pull-through operations. Neurogastroenterol Motil. (2002) 14:643-6. doi: 10.1046/j.1365-2982.2002.00365.x

48. Spiller RC, Brown ML, Phillips SF. Decreased fluid tolerance, accelerated transit, and abnormal motility of the human colon induced by oleic acid. Gastroenterology. (1986) 91:100-7. doi: 10.1016/0016-5085(86)90445-2

49. Spiller RC, Brown ML, Phillips SF. Emptying of the terminal ileum in intact humans. Influence of meal residue and ileal motility. Gastroenterology. (1987) 92:724-9. doi: 10.1016/0016-5085(87)90024-2

50. Stryker SJ, Borody TJ, Phillips SF, Kelly KA, Dozois RR, Beart RW Jr. Motility of the small intestine after proctocolectomy and ileal pouch-anal anastomosis. Ann Surg. (1985) 201:351-6. doi: 10.1097/00000658-198503000-00017

51. Van Ooteghem NAM, Samsom M, Van Erpecum KJ, Van BergeHenegouwen GP. Effects of ileal bile salts on fasting small intestinal and gallbladder motility. Neurogastroenterol Motil. (2002) 14:527-33. doi: $10.1046 / j .1365-2982.2002 .00356 . x$

52. Szurszewski JH. A migrating electric complex of canine small intestine. Am J Physiol. (1969) 217:1757-63. doi: 10.1152/ajplegacy.1969.217.6.1757

53. Husebye E. The patterns of small bowel motility: physiology and implications in organic disease and functional disorders. Neurogastroenterol Motil. (1999) 11:141-61. doi: 10.1046/j.1365-2982.1999.00147.x

54. Hipper K, Ehrlein HJ. Motility of the large intestine and flow of digesta in pigs. Res Vet Sci. (2001) 71:93-100. doi: 10.1053/rvsc.2001.0486

55. Kumar D, Phillips SF, Brown ML. Reflux from ileum to colon in the dog. Role of external ligamentous attachments. Dig Dis Sci. (1988) 33:345-52. doi: 10.1007/BF01535761

56. Kamath PS, Hoepfner MT, Phillips SF. Short-chain fatty acids stimulate motility of the canine ileum. Am J Physiol. (1987) 253(4 Pt 1):G427-33. doi: 10.1152/ajpgi.1987.253.4.G427

57. Spiller RC, Brown ML, Phillips SF, Azpiroz F. Scintigraphic measurements of canine ileocolonic transit. Direct and indirect effects of eating. Gastroenterology. (1986) 91:1213-20. doi: 10.1016/S0016-5085(86)80019-1

58. Jaffe T, Thompson WM. Large-bowel obstruction in the adult: classic radiographic and CT findings, etiology, and mimics. Radiology. (2015) 275:651-63. doi: 10.1148/radiol.2015140916

59. Arkwright JW, Dickson A, Maunder SA, Blenman NG, Lim J, O'Grady $\mathrm{G}$, et al. The effect of luminal content and rate of occlusion on the interpretation of colonic manometry. Neurogastroenterol Motil. (2013) 25:e52-9. doi: 10.1111/nmo.12051 
60. Vather R, Bissett IP. Risk factors for the development of prolonged postoperative ileus following elective colorectal surgery. Int J Colorectal Dis. (2013) 28:1385-91. doi: 10.1007/s00384-013-1704-y

61. Keren DF, Elliott HL, Brown GD, Yardley JH. Atrophy of villi with hypertrophy and hyperplasia of Paneth cells in isolated (thiry-Vella) ileal loops in rabbits. Light-microscopic studies. Gastroenterology. (1975) 68:8393. doi: 10.1016/S0016-5085(75)80052-7

62. Ekelund KM, Ekblad E. Structural, neuronal, and functional adaptive changes in atrophic rat ileum. Gut. (1999) 45:236-45. doi: 10.1136/gut.45.2.236

63. Williams L, Armstrong MJ, Finan P, Sagar P, Burke D. The effect of faecal diversion on human ileum. Gut. (2007) 56:796-801. doi: 10.1136/gut.2006.102046

64. Dinning PG, Wiklendt L, Maslen L, Gibbins I, Patton V, Arkwright JW, et al. Quantification of in vivo colonic motor patterns in healthy humans before and after a meal revealed by high-resolution fiber-optic manometry. Neurogastroenterol Motil. (2014) 26:1443-57. doi: 10.1111/nmo.12408

Conflict of Interest: The authors declare that the research was conducted in the absence of any commercial or financial relationships that could be construed as a potential conflict of interest.

Copyright (c) 2020 Liu, Saw, Dinning, O'Grady and Bissett. This is an open-access article distributed under the terms of the Creative Commons Attribution License (CC $B Y)$. The use, distribution or reproduction in other forums is permitted, provided the original author(s) and the copyright owner(s) are credited and that the original publication in this journal is cited, in accordance with accepted academic practice. No use, distribution or reproduction is permitted which does not comply with these terms. 